\title{
The Effect of Motor Skills on the Elementary School Students' Physical Fitness
}

\author{
Mahardynata Fahmi* \\ Faculty of Sport Science \\ Universitas Negeri Padang \\ Padang, Indonesia \\ mahardynatafahmi07071992@gmail.com
}

\author{
Wilda Wellis \\ Faculty of Sport Science \\ Universitas Negeri Padang \\ Padang, Indonesia
}

\begin{abstract}
The problem of the study was about the lack of physical fitness of elementary school students. This study was revealed to identify the effect of motor skills on elementary school students' physical fitness. The research method was quantitative by using the path analysis approach. The population of the research was all of SD IT students up to 321 people. The sampling technique was taken by total sampling, with a total sample of 43 people. The results of the research and data analysis revealed that Motor skills had a direct and significant effect on the students' physical fitness of 2.89 percent.
\end{abstract}

Keywords - Motor skills, physical fitness

\section{INTRODUCTION}

Good education prioritizes coaching processes that last a lifetime. Physical and health education has an important role in the quality of human resources. Besides, physical education can also develop aspects of individuals that include physical, mental, cognitive, social, moral, spiritual, and others. Physical education provides an opportunity to be directly involved in a variety of learning experiences through physical activities, pay, and sports that are carried out systematically, directed, and planned.

Physical fitness is an important element for elementary school students, so students need to be nurtured from an early age to have strong physical strength and good physical fitness. However, in today's life it is very difficult for children to get used to do an activity that can support their physical fitness and it affects the factors that can support children's daily activities. We can observe this along with the development of technology that children are more likely to engage in activities that do not involve bodily functions that result in suboptimum development of their motor skills.

The scope of physical education subjects for SD / MI, SMP / MTs, and SMA / MA levels actually really helps physical education teachers in preparing, implementing, and evaluating students' activities. The scope of physical education includes aspects of sports games, development activities, gymnastics, rhythmic activities, aquatic, and education outside of school. Therefore, physical education programs are expected to be able to contribute to the process of growth and development of children in the current digital era. "National sports aims to maintain and improve health and fitness, achievement, human quality, instill moral values and noble character, sportsmanship, discipline, strengthen and foster national unity, strengthen national resilience, and raise the dignity, dignity and honor of the nation"[1].

It should be noted that the development of motion of each student is different, if the student only focuses on one thing then the level of growth and development of students is hampered, this can be seen from the lack of activities carried out by the students such as jumping, leaping, throwing, catching, pushing, pulling, and running. All physical activities should be carried out routinely, at least three times a week. However, the time provided by the school for physical education subject is only once a week. Therefore, the students are expected outside of school to be able to do additional physical activity for a minimum of 20-60 minutes a day to maintain their physical fitness.

"Way upgrade fitness One's physical body is one of them exercise properly and regularly so body will continue adapt corresponding with capacity "[2]

The function of the physical education subject in elementary schools is as follows: [a] fulfills the desire for movement $[b]$ stimulates physical growth and development as well as the development of motion [c] maintains and enhances physical health and freshness d) increases the body's resistance to disease [e] reduces boredom and stress [f] instills discipline, cooperation, courage, sportsmanship and follow the rules and regulations.

Motor skills are a child's ability to use a skill that is relatively inherent after childhood. With the ability of children to make movements will certainly motivate to make movements that at the same time contribute to their physical fitness. Motor skills that then act as a foundation for the development of movement skills.

The following is the physical fitness data of the last academic year of SD IT Buah Hati obtained by the researcher from the physical education teacher: Very Good (4.76\%), Good (21.42\%), Moderate (42.86\%), Less $(26.19 \%)$, and Very Less $(4.77 \%)$. With the above data, the percentage of the students' physical fitness is still not good.

The results of the previous studies by Gusril stated that motor ability is largely influenced by many things, including: 1) balance factor, 2) power factor, 3) power receiving factor, 4) locomotor ability, 5) manipulative ability, 6) stable ability and motor ability. Based on the above problems, it is necessary to conduct research that is focused on relating to physical fitness including motor skills of students. The existence of this research certainly 
answered the low physical fitness of the elementary school students at SD IT Buah Hati Padang.

Based on the background of the problem, the researcher conducted a study entitled "The Effect of Motor Skills on the Elementary School Students' Physical Fitness at SDIT Buah Hati Padang."

\section{RESEARCH METHODS}

The method used in this study was a quantitative method using the path analysis approach (Path Analysis), which used structural equations that see the effect of quality dimensions of of Motor Skills (X1), Play Activities (X2), and Nutritional Status (X3) on Physical Fitness (Y). Path Analysis is the relationship between independent variables and dependent variables that are usually presented in the form of diagrams that have arrows that indicate the direction of the influence of exigent and endogen variables. This study was conducted to see the presence or absence of direct and indirect effects variables through the use of the Path Analysis approach.

Path analysis is used to determine whether to reach the final goal must pass through the intermediate variables or can directly affect the intended final goal, that is Physical Fitness (Y) and the intermediate variable is Nutritional Status (X3). While the independent variables (exogenous) in this study are Motor Skills (X1) and Play Activities (X2)[5].

Based on the explanation above, a scheme is drawn to make this study can be directed according to the desired goals. The research scheme is arranged with the research design described as follows:

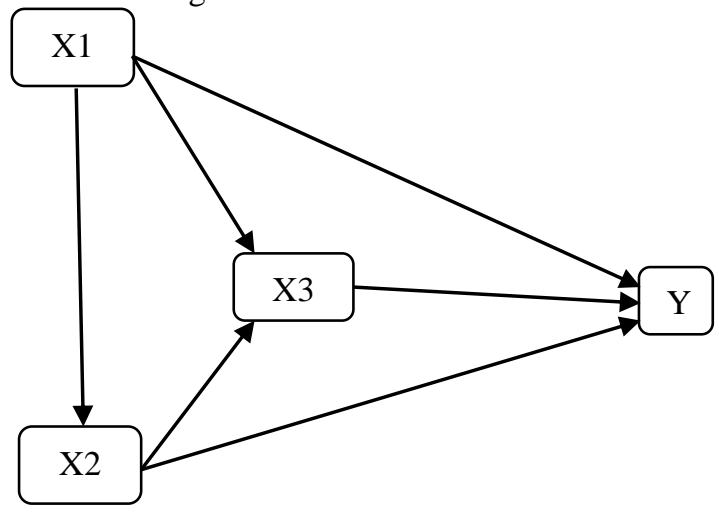

\section{RESEARCH PROCEDURE}

The implementation phase carried out in this study was to determine the population, where the population in this study was all students of SD IT Buah Hati Padang, amounted to 321 people. The research sample was drawn by using purposive sampling and obtained a sample of 43 people (students in grade $5 \mathrm{a}$ and $5 \mathrm{~b}$ ).

To find out the physical fitness level of students aged 10-12 years, the Indonesian Physical Fitness Test (TKJI) was conducted. the Indonesian Physical Fitness Test (TKJI) function in the physical education teaching program includes:
1) Measuring students' physical abilities

2) Determine the status of the students' physical condition.

3) Assessing students' physical abilities as one of the goals of the Physical Education Teaching

4) Knowing the physical development of students.

5) As material to provide guidance in improving physical fitness.

6) As one of the inputs in providing the value of learning from the Health Center[4].

For the elementary school level, it is divided into two groups, namely (1) for grades 1, 2, and 3 and (2) for grades 4,5 , and 6 . This test includes 5 test items, for item types, descriptions and implementation instructions for each item test, described as follows:

a) 40 meter Sprint test

b) 30 seconds Body lift test

c) 30 seconds Lying test

d) Upright Skip Test

e) 600 meter Running test [3]

Through measurements taken by each selected sample used tools for collecting primary data on physical fitness consisting of: (1) Stopwatch, (2) Start flags, (3) Tracks along 40 meters, (4) blackboard erasers, (5) chalk powder, (6) stationery, and (7) blanks evaluation sheet.

Motor skills are the total score of students' ability to measure motor skills, in this case the motor skills used is the Scott Motor Ability Test consisting of: 1) throwing a basketball as measured by meters, 2) running 4 seconds fast as measured by distance in meters, 3) throwing the ball to the wall which is calculated by the number of frequency of the reflection of the ball, 4) long jump without the prefix measured distance jump in meters, 5) obstacle race to measure the coordination of motion. The results of each measurement of each item are recorded on a sheet of paper.

\section{RESULT AND DISCUSSION}

\section{A. The Description of Data}

The result of the assessment of each variable consists of (1) The Description of Research Data, (2) The Testing Requirements Analysis, (3) The Testing Hypotheses through Path Analysis, (4) The Discussion of Research Results, and (5) The Limitations of Research Results.

The summary of basic research data is as follows:

Physical fitness is (Y), 43 students as sample, minimum value is 27.39 , maximal value is 61.25 with an average of 50, median value is 51.58 SD 8.13.

The Physical Fitness Test Results (TKJI) that based on the data analysis of 43 students of SD IT Buah Hati Padang who did a Physical Fitness Test (TKJI) can be described as follows: 


\begin{tabular}{|l|c|c|}
\hline No & $\begin{array}{l}\text { Numbers of } \\
\text { students }\end{array}$ & Category \\
\hline 1 & 5 & Very little \\
\hline 2 & 32 & Less \\
\hline 3 & 5 & Average \\
\hline 4 & 1 & Good \\
\hline 5 & 0 & Very Good \\
\hline
\end{tabular}

Based on the data above, it can be concluded that the physical fitness of the elementary school students in grades $5 \mathrm{a}$ and $5 \mathrm{~b}$ is in the inadequate category.

a) Motor skills (X1), 43 students as sample, minimum value is 24.26 , maximal value is 87.39 , with an average of 50 (mean), median value is $49.58 \mathrm{SD} 10$

Motor Skills Test Results that based on data analysis of 43 students of SD IT Buah Hati Padang who conducted motor skills tests can be described as follows:

\begin{tabular}{|c|c|c|}
\hline No & $\begin{array}{c}\text { Numbers } \\
\text { of Students }\end{array}$ & Category \\
\hline 1 & 2 & Very Good \\
\hline 2 & 9 & Good \\
\hline 3 & 20 & Average \\
\hline 4 & 10 & Less \\
\hline 5 & 2 & Very Little \\
\hline
\end{tabular}

From the above data it can be concluded that the elementary school students' motor skills of grades 5a and $5 \mathrm{~b}$ are in the average category.

\section{B. The Data Analysis Test}

1. The Normality Test

Data is said to be normal if the value of $\mathrm{L}_{0}$ is smaller than $\mathrm{L}_{\text {table. In this study, the data was }}$ taken from the population that is normally distributed in order to be used for testing the research hypotheses.

2. The Homogeneity Test
This test is used to test if the variable data of the physical fitness comes from a homogeneous population. The data of this study came from a homogenous population.

3. The Independent Variable Test

Independent variables are variables that cause changes in the dependent variable, also called variables that affect other variables.

4. The Linearity Test

The purpose is a test conducted to see whether each data variable; motor skills, play activities, and nutritional status tend to from a linear line to the physical fitness variables of the students of SDIT Buah Hati Padang.

5. The Hypothesis Test

This test was carried out by using Path Analysis Approach.

\section{CONCLUSION}

Based on the results of the study, the following conclusions are Motor skills directly affect physical fitness in the average category. This means that the better the motor skills of a student, the better physical fitness will be.

\section{REFERENCES}

[1] Undang-Undang RI Nomor 3 Tahun 2005 Tentang Sistem Keolahragaan Nasional. 2005, pp. 23.

[2] Sepriani, Rika, Eldawaty, "Kebugaran Jasmani Ibu-Ibu Di Jorong Kp. Alai Nagari Jambak Kecamatan Lubuk Sikaping Kabupaten Pasaman", Jurnal Menssana, [S.L.], V. 3, N. 2, P. 47-52, Dec. 2018.

[3] Sugiyono. "Metode Penelitian Pendidikan Kuantitatif, Kualitatif, dan R \& D". Bandung: Alfabeta. 2009, pp. 55.

[4] Nurhasan. "Tes dan Pengukuran dalam Pendidikan Jasmani: Prinsip- Prinsip Dan Penerapannya". Jakarta: Direktorat Jenderal Olahraga. 2001, p. 35.

[5] Nurhasan. "Modul Tes dan Pengukuran Keolahragaan”. Bandung: UPI. 2007, pp. 25. 